4. Low wave energy conditions and high temperatures are optimal physical conditions for growth.

5. Conditions of low wave energy maximize distribution in a narrow band close to high water mark.

The authors would welcome reports of similar incidents of beach fouling elsewhere.

We thank the Environmental Research Unit of the Department of the Environment, the Dublin area local authorities and the EC NORSAP programme for financial support.

D. W. JEFFREY, B. MADDEN and B. RAFFERTY

Department of Botany, Trinity College, Dublin 2, Ireland

Buhr, K. J. \& Winter, J. E. (1977). Distribution and maintenance of a Lanice conchilega association in the Weser estuary (FRG), with special reference to the suspension-feeding behaviour of Lanice conchilega. In Biology of Benthic Organisms (B. F. Keegan, P. O'Ceidigh \& P. J. S. Boaden, eds), pp. 101-113. Pergamon Press, Oxford.

Russell. G. (1966). The genus Ectocarpus in Britain. I. The free-living lorms. J. Mar. Biol. Assoc. UK 46, 267-294.

Wilce, R. T., Schneider, C. W., Quinlan, A. V. \& Van den Bosch, K. (1982). The life history and morphology of free-living Pilayella ittoralis (L.) Kjellm (Ectocarpaceae, Ectocarpales) in Nahant Bay, Massachusetts. Phycologia 21,336-354.

Wilce, R. T. \& Quinjan, A. V. (1983). Fouling of the sandy beaches of Nahant Bay (Massachusetts, USA) by an abnormal free-living form of the macroalga Pilayalla littoralis (L.) Kjellm. (Phaeophyta). II Population characteristics. In Sandy Beaches as Ecosystems (A McLachlan \& T. Erasmus, eds), pp. 285-295. Junk, The Hague.

\section{The Precautionary Principle}

It is with great interest that I read the three Viewpoint papers on the Precautionary Principle (Mar. Pollut. Bull. 24, 182-186, 231-234, and 287-295). I would like to add to the views presented with what, in my opinion, are some of the consequences of the adoption of the precautionary principle for international environmental policy and law. In general, I concur with the viewpoints expressed by Earl, and Peterman \& M'Gonigle, and I believe that the perspective on the precautionary approach expressed below could complement their ideas. As the following illustrates, I, however, dissent with Stebbing's viewpoint, in which he seeks to integrate the environmental capacity and the precautionary principle.

Regardless of all the uncertainties associated with determining the effects of substances on the environment, also pointed out by Stebbing, Stebbing maintains the view that science can be relied on to determine accurately the carrying capacity of the environment. However, it is exactly because science has been shown not to be able to do this that the precautionary principle emerged and has become part of the thinking and practice of several international fora (Boyle, 1992; Freestone, 1991).

The precautionary principle in my opinion is a policy-making strategy. It is not directed at scientific method as such, and it subscribes to the notion that caution should be an integral part of the conduct of scientific research and the presentation of its results.
The precautionary principle addresses the question of how policy makers are to make use of the results of scientific research. That is, it addresses how policymakers are to deal with, what is a fact of life, inconclusive scientific evidence.

In my view the essence of the precautionary principle is that it aims at bringing about a shift in the way policymakers regard the relationship between environment, science, technology, and economics. It advocates a movement away from the primate of scientific proof and traditional economic analyses that does not account for environmental degradation. The precautionary principle assumes that science does not always provide the insights needed to effectively protect the environment and that undesirable effects may be caused if measures are taken only when science does provide such insights. Furthermore, it assumes that scarce financial means may be wasted if action to protect the environment is taken only when scientific certainty is available.

The essence of the shift which the precautionary principle seeks to bring about can be illustrated as follows:

- the environmental capacity approach emphasizes:

1. the carrying capacity of the environment;

2. the ability of science to accurately predict threats

to the environment and the measures required to prevent such threats;

3. the availability of technical possibilities to mitigate threats once they have been accurately predicted; and 4. the reliance on short term economic considerations, while emphasizing the unreliability of long term economic considerations and uncertainties involved in determining the present value of future environmental degradation.

- the precautionary principle emphasizes:

- the vulnerability of the environment;

- the limitations of science to accurately predict threats to the environment and the measures required to prevent such threats;

- the availability of practical alternatives (both methods of production and products) which enable the termination or minimization of inputs into the environment; and

- the need for long term holistic economic considerations, accounting for, among others, environmental degradation and the cost of waste treatment.

The above indicates that I do not regard scientific method as such as the main addressee of the precautionary principle. However, this does not mean that the principle is without consequences for scientific research. It addresses, at least, two questions related to scientific research: $l$. the question of which type of scientific research needs to be emphasized, e.g. research seeking new clean production technologies rather than research seeking to determine the assimilative capacity of the environment for substance $x$; and 2. the question of the role of science in determining policy, i.e. value judgements as to what should and should not be policy given socio-economic factors ultimately are the responsibility of the policy-maker, not the scientists (also see the discussion on the precautionary principle 
between Gray; and Johnston \& Simmonds, Lutter, Josefson, Lawrence \& Taylor: Mar. Pollut. Bull. 21, 174-176, 402, 547-548, 598-600).

Elsewhere (Hey, 1992), I have forwarded the following elements for a definition of the precautionary principle and approach.

\section{The precautionary principle}

In order to ensure the protection and the preservation of the environment and attain sustainable development, lack of scientific certainty shall not be used as a reason for deferring measures to enhance the quality of the environment. In order to achieve this a precautionary approach shall be adopted.

\section{The precautionary approach}

This means that:

- clean production methods, best available technology and best environmental practices shall be applied;

- comprehensive methods of environmental and economic assessment shall be used in deciding upon measures to enhance the quality of the environment;

- research, especially scientific research and economic research, contributing to a better understanding of the long term policy-options available shall be stimulated; and

- legal, administrative and technical procedures which facilitate the implementation of this approach shall be applied and, where not available developed.

The above definition implies that implementation of the precautionary principle and approach has con- sequences for, among others, international legal, administrative and technical procedures. The development of the New Assessment Procedure within the framework of the London Dumping Convention (Thorne-Miller, 1992) illustrates that this is also being recognized by international forums. However, if implementation of the precautionary principle and approach is to be achieved the development of procedures which institutionalize caution requires further thought by both practitioners and scholars. I suggest that, the following are among the issues which require consideration: voting procedures; assessment procedures; the role of conciliation commissions, inspection teams and fact-finding missions; provisional application of agreements; development of 'soft law'; public and NGO participation; access to information.

\section{ELLEN HEY}

Faculty of Law, Erasmus University Rotterdam, P.O. Box 1738, 3000 DR Rotterdam, The Netherlands

Boyle, A. E. (1992). Protecting the marine environment: some problems and developments in the law of the sea. Mar. Pol. 16, 7985.

Freestone, D. (1991). The Precautionary Principle. In International Law and Global Climate Change (R. R. Churchill \& D. Freestone, eds), pp. $21-39$.

Hey, E. (1992). The Precautionary Concept in Environmental Law and Policy: Institutionalizing Caution. Georgetown International Environmental Law Review 5, 303-318.

Thorne-Miller, B. (1992). The LDC, The Precautionary Approach, and the Assessment of Wastes for Sea-Disposal. Mar. Pollut. Bull. 24, $335-339$.

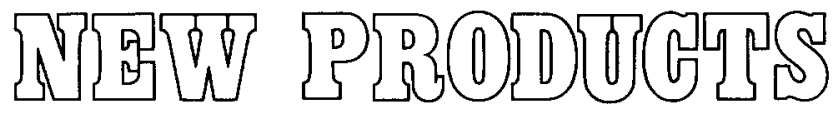

\section{Water Quality Monitoring- An Integrated Approach}

An integrated approach towards achieving optimum water quality comes with the development by KentTaylor of a new monitoring system which combines facilities to measure $\mathrm{pH}$, conductivity, dissolved oxygen, temperature and turbidity in a single package.

Known as the EIL 7976, this multi-parameter water quality monitoring system has been designed to meet increasing demands for continuous on-line monitoring of natural water courses, reservoirs and intake protection sites. It is a compact instrument which is easy to use and maintain, has a simple, time-saving calibration procedure and features low cost installation and operation. Furthermore, the IP65 casing ensures full protection of the instrument in virtually any location.

Although unified in a single system design, the major elements comprise standard proven products from the Kent-Taylor range.

The Company's well-established 4500 transmitter series forms the basis of the package-namely, the 4512 combined $\mathrm{pH}$ and conductivity monitor and the 4555 dissolved oxygen and temperature transmitter. The BTG 3000 turbidity transmitter, supplied as standard, may be replaced by an end-user's preference, subject to compatibility with the rest of the instrumentation. The liquid handling section comprises the sample inlet containing the turbidity sensor, followed by the flow line conductivity cell and the 7601 flow system incorporating the $\mathrm{pH}$, dissolved oxygen and temperature probes.

Two fully adjustable and security protected set point alarms are provided for each of the $\mathrm{pH}$, conductivity, dissolved oxygen and temperature measuring channels, and there are turbidity alarms for high suspended solids and probe failure.

Installation costs and commissioning time is minimized, since all connecting cables between the sensors and transmitters are supplied ready wired. Calibration-unnecessary on the conductivity units-is semiautomatic for $\mathrm{pH}$ and dissolved oxygen.

For the more demanding applications, the EIL 7976 can be fitted with a biocide cleaning facility which is activated at predetermined intervals to enhance the reliability of the sensors. 